\title{
Incidence of Contrast Induced Acute Kidney Injury, Its Risk Factors and In-Hospital Outcomes in Patients Undergoing Coronary Angiography and Angioplasty
}

\author{
Prashun Upadhaya', Pradeep Thapa ${ }^{2}$, Ratna M Gajurel' ${ }^{3}$, Mahesh R Sigdel ${ }^{4}$ \\ ${ }^{1}$ Alka Hospital, Jawalakhel, Lalitpur, ${ }^{2}$ Department of Internal Medicine, College of Medical Sciences, Bharatpur, \\ ${ }^{3}$ Department of Cardiology, Maharajgunj Medical Campus, Manmohan Cardiothoracic Vascular and Transplant \\ Centre, Institute of Medicine, Kathmandu, Nepal, ${ }^{4}$ Department of Nephrology, Maharajgunj Medical Campus, \\ Tribhuvan University Teaching Hospital, Institute of Medicine, Kathmandu, Nepal.
}

\section{Corresponding author:}

Prashun Upadhaya, MBBS, MD

Alka Hospital, Jawalakhel, Lalitpur

Email:prashun_889@hotmail.com

Submitted : Jun 24, 2020

Accepted : Jul 30, 2020

\begin{abstract}
\section{Introduction}

Contrast-induced acute kidney injury $(\mathrm{Cl}-\mathrm{AKI})$ is a serious complication of angiographic procedures with significant morbidity and mortality. We aimed to find the incidence, risk factors and outcomes of $\mathrm{Cl}-\mathrm{AKI}$ in patients who have undergone coronary angiography/angioplasty in a referral hospital in Nepal.
\end{abstract}

\section{Methods}

It was a descriptive observational study of consenting consecutive patients above 18 years undergoing coronary angiography/angioplasty at Manmohan Cardiothoracic Vascular and Transplant Centre, Nepal from July 2015 to September 2017. Cl AKI was defined as an elevation of serum creatinine of $>25 \%$ or $\geq 0.5 \mathrm{mg} / \mathrm{dl}$ ( $44 \mu \mathrm{mol} / \mathrm{L})$ from baseline within 48 hour of exposure to contrast. Statistical analysis was performed using SPSS 18 software. Statistical analysis was completed using Student's t-test, chi-square test and multivariable logistic regression analysis.

\section{Results}

Out of 240 patients, 156 (65\%) were male, mean age was $60.36 \pm 11.29$ years. Eighteen patients (7.5\%) developed $\mathrm{Cl}$-AKI. Incidence of $\mathrm{Cl}$-AKI was $20 \%$ in patients with chronic kidney disease (CKD), $5.4 \%$ in diabetics, $13.6 \%$ in patients $>70$ years, $12.79 \%$ in patients with anaemia and $12.3 \%$ in patients with prior contrast exposure. Multivariate logistic regression analysis found smoking and history of prior contrast exposure to be independent predictors for development of $\mathrm{Cl}-\mathrm{AKI}$. Among patients with $\mathrm{Cl}-\mathrm{AKI}$, one (5.88\%) required dialysis and one (5.88\%) died.

\section{Conclusion}

Incidence of $\mathrm{Cl}-\mathrm{AKI}$ after coronary angiography/angioplasty was $7.5 \%$. Patients with prior contrast exposure and smoking were at significantly increased risk of $\mathrm{Cl}-\mathrm{AKI}$; higher trend of $\mathrm{Cl}-\mathrm{AKI}$ was seen in patients with CKD, diabetes, elderly and anaemia.

Keywords: Angiography, angioplasty, contrast induce acute kidney injury, contrast media" contrast nephropathy 


\section{INTRODUCTION}

$\mathrm{N}$ ephropathy induced by exposure to contrast agents is associated with significant inhospital and long-term morbidity and mortality. ${ }^{1}$ Patients with pre-existing renal failure are at particularly high risk.2,3

The reported incidence of $\mathrm{Cl}-\mathrm{AKI}$ varies widely. It is low $(1-2 \%)$ in patients with normal kidney function ${ }^{4}$ and may be as high as $25 \%$ in patients with preexisting renal impairment or in presence of certain risk factors, such as chronic kidney disease (CKD), diabetes, congestive heart failure (CHF), advanced age, and concurrent administration of nephrotoxic drugs. ${ }^{5}$

The most likely cause of $\mathrm{Cl}-\mathrm{AKI}$ is acute tubular necrosis (ATN) secondary to medullary hypoxia. ${ }^{6,7}$ Medullary hypoxia may result from increased viscosity, disturbed balance between nitric oxide, endothelin, and/or adenosine and direct result of the cytotoxic effects of the contrast agents on tubular cells. ${ }^{6-9}$ In patients who develop Cl-AKI, greater the increase in serum creatinine, greater is the risk of adverse outcome. ${ }^{10}$

Increasing cardiovascular disease burden leads to increase in use of diagnostic and therapeutic cardiac interventions exposing patients to contrast media and the subsequent risk. This study was undertaken to study the incidence of $\mathrm{Cl}-\mathrm{AKI}$ and to identify risk factors (predictors) for its development in patients undergoing coronary angiography / angioplasty and to document the in-hospital outcomes of the same.

Having such data in Nepalese population help in stratifying risks and undertake preventive measures for Cl-AKI.

\section{METHODS}

It was a cross-sectional descriptive observational study conducted in the Department of Cardiology, Manmohan Cardiothoracic Vascular and Transplant Centre (MCVTC), Institute of Medicine (IOM), Nepal. The study was conducted from July 2015 to September 2017 after obtaining ethical approval from the Institutional Review Committee (IRC) of IOM. The sample size was calculated using STATA S.E version 13 with power of $80 \%$. The required sample size was 239. We included 240 patients in the study. Adult patients undergoing angiography and angioplasty and who signed informed consent were eligible for the study.

Cl-AKI was defined as a rise in serum creatinine of $\geq 0.5 \mathrm{mg} / \mathrm{dl} \quad(\geq 44 \mathrm{mmol} / \mathrm{l})$ or a $25 \%$ increase from base-line value, assessed at 48 hours after a radiological procedure. ${ }^{11}$ Anaemia was defined as haemoglobin $(\mathrm{Hb})$ levels $<12.0 \mathrm{~g} / \mathrm{dL}$ in women and $<13.0 \mathrm{~g} / \mathrm{dL}$ in men according to World Health Organization (WHO) criteria. $^{12}$ Hypertension was diagnosed as blood pressure of $\geq 140 / 90 \mathrm{~mm} \mathrm{Hg}$ or in a person who was under antihypertensive medications regardless of the observed blood pressure based on the definition by the seventh report of the Joint National Committee diagnosis. ${ }^{13}$ Diabetes was diagnosed as per American Diabetes Association (ADA) criteria ${ }^{14}$ if any of the following criteria were met: Fasting plasma glucose $\geq 126$ $\mathrm{mg} / \mathrm{dl}(7.0 \mathrm{mmol} / \mathrm{L})$ or Two-hour plasma glucose $\geq 200 \mathrm{mg} / \mathrm{dl}(11.1 \mathrm{mmol} / \mathrm{L})$ during an oral glucose tolerance test or a random plasma glucose $\geq 200$ $\mathrm{mg} / \mathrm{dl}(11.1 \mathrm{mmol} / \mathrm{L})$ in a patient with classic symptoms of hyperglycaemia or hyperglycaemic crisis or $\mathrm{HbA}_{1} \mathrm{C} \geq 6.5$. Smoker was described as a person who had smoked at least 100 cigarettes in lifetime but had quit at the time of interview. ${ }^{15}$

All patients undergoing angiography or angioplasty at the treating cardiologist's discretion at MCVTC were enrolled in the study. The relevant baseline clinical and laboratory parameters were recorded. Serum creatinine level was documented at baseline and 48 hours after the procedure. Record was also kept about the volume of contrast used, type of angiographic procedure (i.e. diagnostic or interventional), its findings, post-procedural complications, duration of hospital stay, requirement of dialysis and death due to Cl-AKI. Estimated Glomerular filtration rate was calculated using the Modification of Diet in Renal disease (MDRD) equation. ${ }^{16}$

Patients who were considered at risk of developing $\mathrm{Cl}^{-A K I}{ }^{5}$, received hydration in the form of I.V normal saline and oral Acetylcysteine at a dose of $600 \mathrm{mg}$ twice daily prior to the procedure to reduce the subsequent risk of developing $\mathrm{Cl}$-AKI.

Continuous variables were presented as mean \pm SD and compared using Student's t test. Categorical variables were presented as counts and percentages and compared with $\chi^{2}$-test. A multivariable logistic regression analysis was used to identify independent characteristics associated with CI-AKI. A $p$ value of $\leq 0.05$ was considered statistically significant. All data were processed using SPSS version 18.

\section{RESULTS}

Out of total of 240 studied patient, $156(65 \%)$ were male and 84 (35\%) were female. The mean age of patients included in the study was $60.3 \pm 11.2$ years. Eighteen (7.5\%) patients developed Cl-AKI (figure 1). The baseline characteristics of the patients with $\mathrm{Cl-AKI}$ are shown in the table 1.

The baseline mean serum creatinine of patients without $\mathrm{Cl}-\mathrm{AKI}$ and with $\mathrm{Cl}-\mathrm{AKI}$ was similar $(0.981 \pm$ $0.062 \mathrm{mg} / \mathrm{dl}$ and $0.993 \pm 0.119 \mathrm{mg} / \mathrm{dl} \mathrm{p}=0.62$ ). Though Cl-AKI group received higher volume of contrast than non-Cl-AKI group, the difference was not statistically significant (153.8 \pm 5.7 vs $86.9 \pm$ 


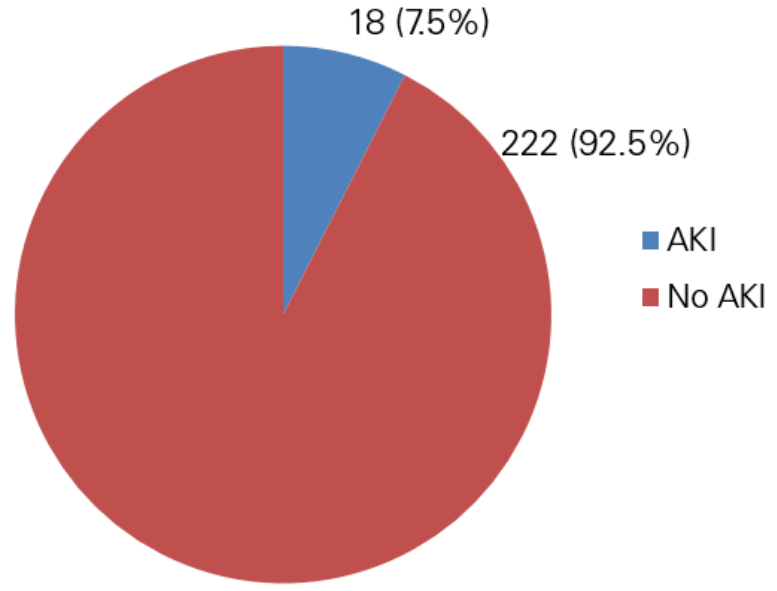

Fig 1. Incidence of contrast induced AKI

Table 1. Baseline characteristics of the study population

\begin{tabular}{lc}
\hline \multicolumn{1}{c}{ Variables } & Values \\
\hline Age (years) & $60.3 \pm 11.2$ \\
Male sex - no. (\%) & $156(65)$ \\
Systolic BP (mmHg) & $134.9 \pm 24.4$ \\
Diastolic BP (mmHg) & $76.9 \pm 12.9$ \\
Estimated GFR (ml/min/1.73m²) & $90.0 \pm 26.7$ \\
Hemoglobin (mg/dl) & $12.9 \pm 2.2$ \\
Contrast volume (ml) & $156.3 \pm 86.3$ \\
Hypertension - no. (\%) & $121(50.4)$ \\
Diabetes Mellitus - no. (\%) & $74(30.8)$ \\
Chronic Kidney disease - no. (\%) & $5(2.1)$ \\
Smoking - no. (\%) & $105(43.8)$ \\
History of contrast exposure - no. (\%) & $65(27.1)$ \\
Hydration - no. (\%) & $141(58.7)$ \\
N-acetyl cysteine - no. (\%) & $43(17.9)$ \\
\hline
\end{tabular}

20.0; $p=0.91)$.

Multivariate Logistic Regression Analysis revealed that the relative risk (RR) for the Cl-AKI after exposure to contrast agent was significant for smoking (RR 7.6, 95\%, Cl 1.06 to 54.9) ( $p=0.047)$ and history of prior contrast exposure (RR 7.8, $95 \% \mathrm{Cl} 1.6$ to 37.7$)(\mathrm{p}=0.01)$.

The incidence of $\mathrm{Cl}-\mathrm{AKI}$ was similar for the percutaneous coronary intervention (PCl) and non$\mathrm{PCl}$ group $(8.77 \% \mathrm{vs} \quad 4.3 \% \quad \mathrm{p}=0.23)$.Other risk factors such as age $>70$ years, anemia, diabetes, hypertension, CKD, heart failure were not significantly associated with development of Cl-AKI. Similarly, use of hydration and N-Acetyl cysteine (NAC), Left ventricular (LV) function did not significantly impact development of Cl-AKI (Table 2).

Of the total patients who developed Cl-AKI (18
Table 2. Overall incidence of CI-AKI after coronary angiography/angioplasty

\begin{tabular}{|c|c|c|c|}
\hline \multirow{2}{*}{ Risk factors } & \multicolumn{2}{|c|}{$\begin{array}{c}\text { Incidence of } \\
\text { AKI }\end{array}$} & \multirow[t]{2}{*}{$p$ value } \\
\hline & No. & $\%$ & \\
\hline $\begin{array}{l}\text { Age }>70 \text { years } \\
\text { Age }<70 \text { years }\end{array}$ & $\begin{array}{c}7 / 52 \\
11 / 188\end{array}$ & $\begin{array}{l}13.6 \% \\
5.8 \%\end{array}$ & 0.06 \\
\hline $\begin{array}{l}\text { Hypertension } \\
\text { Non-hypertensive }\end{array}$ & $\begin{array}{l}9 / 121 \\
9 / 119\end{array}$ & $\begin{array}{l}7.4 \% \\
7.5 \%\end{array}$ & 0.97 \\
\hline $\begin{array}{l}\text { Diabetes } \\
\text { Non diabetics }\end{array}$ & $\begin{array}{c}4 / 74 \\
14 / 166\end{array}$ & $\begin{array}{l}5.4 \% \\
8.5 \%\end{array}$ & 0.40 \\
\hline $\begin{array}{l}\text { CKD } \\
\text { Without CKD }\end{array}$ & $\begin{array}{c}1 / 5 \\
18 / 235\end{array}$ & $\begin{array}{l}20 \% \\
7.8 \%\end{array}$ & 0.28 \\
\hline $\begin{array}{l}\text { Smoker } \\
\text { Non-smoker }\end{array}$ & $\begin{array}{l}11 / 105 \\
4 / 135\end{array}$ & $\begin{array}{l}11.1 \% \\
2.8 \%\end{array}$ & 0.02 \\
\hline $\begin{array}{l}\text { History of previous } \\
\text { contrast exposure } \\
\text { No previous contrast } \\
\text { exposure }\end{array}$ & $10 / 175$ & $\begin{array}{l}12.3 \% \\
5.7 \%\end{array}$ & 0.047 \\
\hline $\begin{array}{l}\mathrm{N} \text {-acetyl cysteine used } \\
\mathrm{N} \text {-acetyl cysteine not used }\end{array}$ & $\begin{array}{c}3 / 43 \\
27 / 197\end{array}$ & $\begin{array}{c}6.1 \% \\
13.9 \%\end{array}$ & 0.07 \\
\hline $\begin{array}{l}\text { Hydration } \\
\text { No hydration }\end{array}$ & $\begin{array}{c}12 / 141 \\
6 / 99\end{array}$ & $\begin{array}{l}8.51 \% \\
6.1 \%\end{array}$ & 0.47 \\
\hline $\begin{array}{l}\text { Anaemia } \\
\text { Non anaemic }\end{array}$ & $\begin{array}{l}12 / 97 \\
7 / 143\end{array}$ & $\begin{array}{l}12.8 \% \\
4.89 \%\end{array}$ & 0.06 \\
\hline $\begin{array}{l}\text { Left ventricular systolic } \\
\text { function }\end{array}$ & & & \\
\hline $\begin{array}{l}\text { Normal } \\
\text { Mild LVSD } \\
\text { Moderate LVSD } \\
\text { Severe LVSD }\end{array}$ & $\begin{array}{c}5 / 112 \\
5 / 50 \\
9 / 69 \\
0 / 9\end{array}$ & $\begin{array}{c}4.5 \% \\
8 \% \\
13.0 \% \\
0\end{array}$ & 0.15 \\
\hline
\end{tabular}

patients), dialysis support was required in one patient $(5.88 \%)$ and death occurred in the same patient. In the rest of the patients including the patient with CKD, serum creatinine returned to the baseline value within a week.

\section{DISCUSSION}

The risk of Cl-AKI may be very high in patients undergoing percutaneous coronary angiography due to presence of multiple risk factors. ${ }^{2,3} \mathrm{Cl}-\mathrm{AKI}$ is the third most common cause of acute renal failure and is responsible for $11 \%$ cases of hospital acquired renal insufficiency. ${ }^{1}$ The mean age of patients in the present study was $60.36 \pm 11.29$ years, $65 \%$ were male which is similar to a study by Bradley et al. ${ }^{17}$

The overall incidence of $\mathrm{Cl}-\mathrm{AKI}$ in our study is $7.5 \%$ which is similar to a study by Nough et al. ${ }^{18}$ Preexisting renal functional impairment is the most important risk factor for developing $\mathrm{Cl}-\mathrm{AKI} .{ }^{19} \mathrm{We}$ observed $\mathrm{Cl}-\mathrm{AKI}$ in $20 \%$ of patients with CKD and the 
overall mortality rate of $0.41 \%$ which is consistent with the finding of the Visipaque Angiography/ Interventions with Laboratory Outcomes in Renal Insufficiency (VALOR) Trial ${ }^{20}$ and study by Weisbord et al. ${ }^{10}$ Our study had only five patients with CKD and none of them required dialysis. A study by Freeman et al. showed dialysis requirement in almost $4 \%$ of patients with underlying renal impairment. ${ }^{21}$ This difference could be due to small number of patients with CKD in our study who were exposed to contrast agent.

In this study, the incidence of $\mathrm{Cl}-\mathrm{AKI}$ in patients $>70$ years was $13.46 \%$ compared with $5.8 \%$ in patients $<70$ years of age $(p=0.06)$. This result is consistent with the study by McCullough et al where age above 70 appeared to be an independent predictor of $\mathrm{Cl}$ $\mathrm{AKI}^{2}{ }^{2}$ Similarly, in a study by Rich et al the incidence of $\mathrm{Cl}-\mathrm{AKI}$ among the patients 70 years or older was $11 \% .{ }^{22}$ The reasons for this higher risk of $\mathrm{Cl}-\mathrm{AKI}$ are probably multifactorial, including age-related changes in renal function, the presence of multivessel disease, and more difficult vascular access requiring relatively large amounts of contrast.

Multivariate logistic regression analysis showed that history of smoking and prior history of contrast administration were independent risk factors for $\mathrm{Cl}-\mathrm{AKI}$ in the study population. Published literature quote smoking as a minor risk factor for $\mathrm{Cl}$-AKI. ${ }^{23}$ In a human clinical controlled study, smoking and nicotine were accompanied by significant acute changes in renal hemodynamic and albuminuria. ${ }^{24}$ This could be the possible reason for the increase risk of $\mathrm{Cl}$-AKI in patients who smoke. ${ }^{24}$ The risk of $\mathrm{Cl}$ AKI after repeated contrast exposure was evaluated by Trivedi et a ${ }^{25}$ where significant increase in mean serum creatinine and decline in eGFR after a second exposure was observed with the incidence of $\mathrm{Cl}-\mathrm{AKI}$ of $14.3 \%$. In our study this incidence was $12.3 \%$ as compared to $5.74 \%$ in patients without prior exposure to the contrast agent. This difference was statistically significant with $p=0.047$. This highlights the importance of minimising repeat exposure to contrast agent. The minimum interval after which patients in our study underwent repeat exposure to contrast was three days.

Anaemia is an established risk factor for the development of Cl-AKI. A study by Nikolsky et al. ${ }^{26}$ found that lower baseline haematocrit was an independent predictor of contrast-induced nephropathy. A study by Dangas and colleagues ${ }^{27}$ showed lower baseline haematocrit were most significant independent predictors of Cl-AKI. In our study the incidence of $\mathrm{Cl}-\mathrm{AKI}$ in patients with anaemia was $12.79 \%$ and without anaemia was $4.89 \%(p=0.06)$. Even though the difference was not statistically significant there is trend towards higher incidence of Cl-AKI in patients with anemia at baseline. The combination of contrast-induced vasoconstriction and anaemia may decrease oxygen delivery sufficiently to cause renal medullary hypoxia and subsequently acute medullary necrosis. Thus Anaemia-induced deterioration of renal ischemia and hypoxia may be one reason for the higher incidence of $\mathrm{Cl}-\mathrm{AKI}$ in anaemic patients. ${ }^{7}$

The beneficial effect of the use of $\mathrm{N}$-acetyl cysteine (NAC) for the prevention of $\mathrm{Cl}$-AKI is uncertain. ${ }^{28}$ In the present study, the incidence of Cl-AKI who did and did not receive NAC were $6.09 \%$ and $13.95 \%$ respectively $(P=0.07)$. Based on this finding, the potential benefit of NAC to prevent Cl-AKI needs to be further explored in larger randomized well controlled clinical trials.

All patients received low molecular weight contrast media, lohexol. The volume of contrast agent administered for the $\mathrm{Cl}-\mathrm{AKI}$ group and non-Cl-AKI group were similar $(153.8 \pm 5.7$ and $86.9 \pm 20.09$; $\mathrm{P}=0.91$ ). No correlation was observed between the amount of contrast agent administered and the change in serum creatinine. There is a debate whether the quantity of contrast agent predicts

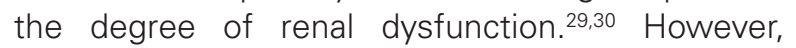
there is a general consensus on the use of small dose of contrast agent and hence the avoidance of repeated, closely spaced studies (within 48 to 72 hours) represents one of the most important recommendations to prevent $\mathrm{Cl}-\mathrm{AKI} .{ }^{31}$ These preventive measures become even more important when dealing with patients with impaired renal function.

We do acknowledge some of the limitations of this study. Because of its observational design, definite causal relationship could not be established between development of $\mathrm{Cl}$-AKI and other variables. The sample size was relatively small. Less number of patients with impaired baseline renal function were exposed to contrast agent in our study. In a few patients, rise in serum creatinine could have occurred after 48 hours ${ }^{11}$, which might have resulted in underestimation of $\mathrm{Cl}-\mathrm{AKI}$ in our study. Another limitation was the use of MDRD equation for estimating eGFR as its performance is not known in Nepalese population.

\section{CONCLUSION}

The incidence of contrast induced acute kidney injury was $7.5 \%$ in our study. Smoking and history of prior contrast exposure were independently associated with a higher risk of development of $\mathrm{Cl}$ AKI. Age more than 70 years and anaemia appeared to pose higher risk of development of Cl-AKI. Use of $\mathrm{N}$-acetyl cysteine could have a role for prevention of Cl-AKI.

\section{CONFLICT OF INTEREST}

None declared. 


\section{ACKNOWLEDGEMENTS}

We are grateful to the patients who gave consent for the study. We are thankful to Prof Dr Amod Poudyal for his help in statistics.

\section{REFERENCES}

1. Nash K, Hafeez A, Hou S. Hospital-acquired renal insufficiency. Am J Kidney Dis. 2002 May;39(5):930-6.

2. McCullough PA, Wolyn $R$, Rocher $L L$, et al. Acute renal failure after coronary intervention: incidence, risk factors, and relationship to mortality. Am J Med. 1997 Nov; 103(5):368-75.

3. Gruberg $L$, Mehran R, Dangas $G$, et al. Acute renal failure requiring dialysis after percutaneous coronary interventions. Catheter Cardiovasc Interv. 2001 Apr;52(4):409-16.

4. Berns AS. Nephrotoxicity of contrast media. Kidney Int [Internet]. 1989 Oct 1;36(4):730-40. Available from: https://doi.org/10.1038/ ki. 1989.254

5. Rudnick MR, Goldfarb S, Tumlin J. Contrast-induced nephropathy: is the picture any clearer? Clin J Am Soc Nephrol. 2008 Jan;3(1):2612.

6. Detrenis S, Meschi M, Musini S, et al. Lights and shadows on the pathogenesis of contrast-induced nephropathy: state of the art. Vol. 20, Nephrology, dialysis, transplantation: official publication of the European Dialysis and Transplant Association - European Renal Association. England; 2005. p. 1542-50.

7. Heyman SN, Rosenberger C, Rosen S. Regional alterations in renal haemodynamics and oxygenation: a role in contrast mediuminduced nephropathy. Nephrol Dial Transplant Off Publ Eur Dial Transpl Assoc - Eur Ren Assoc. 2005 Feb;20 Suppl 1:i6-11.

8. Weisberg LS, Kurnik PB, Kurnik BR. Radiocontrast-induced nephropathy in humans: role of renal vasoconstriction. Kidney Int. 1992 May;41(5):1408-15.

9. Pflueger A, Larson TS, Nath KA, et al. Role of adenosine in contrast media-induced acute renal failure in diabetes mellitus. Mayo Clin Proc. 2000 Dec;75(12):1275-83.

10. Weisbord SD, Chen H, Stone RA, Kip KE, Fine MJ, Saul MI, et al. Associations of increases in serum creatinine with mortality and length of hospital stay after coronary angiography. J Am Soc Nephrol. 2006 Oct;17(10):2871-7.

11. Khwaja A. KDIGO clinical practice guidelines for acute kidney injury. Nephron Clin Pract. 2012;120(4):c179-84.

12. Anaemias WHOSG on N, Organization WH. Nutritional anaemias: report of a WHO scientific group [meeting held in Geneva from 13 to 17 March 1967] [Internet]. Geneva PP - Geneva: World Health Organization; 1968. (World Health Organization technical report series; no. 405). Available from: https://apps.who.int/iris/ handle/10665/40707

13. Chobanian A V, Bakris GL, Black HR, et al. The Seventh Report of the Joint National Committee on Prevention, Detection, Evaluation, and Treatment of High Blood Pressure: the JNC 7 report. JAMA. 2003 May;289(19):2560-72.

14. Association AD. Diagnosis and classification of diabetes mellitus. Diabetes Care [Internet]. 2011 Jan;34 Suppl 1(Suppl 1):S62-9. Available from: https://www.ncbi.nlm.nih.gov/pmc/articles/ PMC3006051/

15. NHIS-Adult Tobacco Use-Glossary [Internet]. Centers for Disease Control and Prevention (CDC). Available from: https://www.cdc. gov/nchs/nhis/tobacco/tobacco_glossary.htm.

16. Levey AS, Bosch JP, Lewis JB, et al. A more accurate method to estimate glomerular filtration rate from serum creatinine: a new prediction equation. Modification of Diet in Renal Disease Study Group. Ann Intern Med. 1999 Mar;130(6):461-70.

17. Bradley SM, Spertus JA, Kennedy KF, et al. Patient selection for diagnostic coronary angiography and hospital-level percutaneous coronary intervention appropriateness: insights from the National Cardiovascular Data Registry. JAMA Intern Med. 2014 Oct;174(10):1630-9.

18. Nough $H$, Eghbal $F$, Soltani $M$, et al. Incidence and main determinants of contrast-induced nephropathy following coronary angiography or subsequent balloon angioplasty. CardioRenal Med. 2013;3(2):128-35.

19. Mehran R, Nikolsky E. Contrast-induced nephropathy: definition, epidemiology, and patients at risk. Kidney Int Suppl. 2006 Apr;(100):S11-5.

20. Rudnick MR, Davidson C, Laskey W, et al. Nephrotoxicity of iodixanol versus ioversol in patients with chronic kidney disease: the Visipaque Angiography/Interventions with Laboratory Outcomes in Renal Insufficiency (VALOR) Trial. Am Heart J. 2008 Oct;156(4):776-82.

21. Freeman R V, O'Donnell M, Share $D$, et al. Nephropathy requiring dialysis after percutaneous coronary intervention and the critical role of an adjusted contrast dose. Am J Cardiol. 2002 Nov;90(10):1068-73.

22. Rich MW, Crecelius CA. Incidence, risk factors, and clinical course of acute renal insufficiency after cardiac catheterization in patients 70 years of age or older. A prospective study. Arch Intern Med. 1990 Jun;150(6):1237-42.

23. Lindholt JS. Radiocontrast induced nephropathy. Eur J Vasc Endovasc Surg [Internet]. 2003 Apr 1;25(4):296-304. Available from: https://doi.org/10.1053/ejvs.2002.1824

24. Ritz $E$, Benck $U$, Franek $E$, et al. Effects of smoking on renal hemodynamics in healthy volunteers and in patients with glomerular disease. J Am Soc Nephrol. 1998;9(10):1798-804.

25. Trivedi H, Foley WD. Contrast-induced nephropathy after a second contrast exposure. Ren Fail. 2010;32(7):796-801.

26. Nikolsky E, Mehran R, Lasic Z, et al. Low hematocrit predicts contrast-induced nephropathy after percutaneous coronary interventions. Kidney Int. 2005 Feb;67(2):706-13.

27. Dangas G, lakovou I, Nikolsky E, et al. Contrast-induced nephropathy after percutaneous coronary interventions in relation to chronic kidney disease and hemodynamic variables. Am J Cardiol. 2005 Jan;95(1):13-9.

28. Webb JG, Pate GE, Humphries $\mathrm{KH}$, et al. A randomized controlled trial of intravenous $\mathrm{N}$-acetylcysteine for the prevention of contrastinduced nephropathy after cardiac catheterization: lack of effect. Am Heart J. 2004 Sep;148(3):422-9.

29. Rihal CS, Textor SC, Grill DE, et al. Incidence and prognostic importance of acute renal failure after percutaneous coronary intervention. Circulation. 2002 May; 105(19):2259-64.

30. Manske CL, Sprafka JM, Strony JT, et al. Contrast nephropathy in azotemic diabetic patients undergoing coronary angiography. Am J Med. 1990 Nov;89(5):615-20.

31. Barrett BJ, Carlisle EJ. Metaanalysis of the relative nephrotoxicity of high- and low-osmolality iodinated contrast media. Radiology. 1993 Jul;188(1):171-8. 